Original Article

\title{
Seasonality and forest edge as drivers of Tradescantia zebrina Hort. ex Bosse invasion in the Atlantic Forest
}

\author{
Sazonalidade e efeito de borda florestal como direcionadores da invasão de \\ Tradescantia zebrina Hort. ex Bosse na Mata Atlântica
}

\author{
W. A. Chiba de Castro ${ }^{a^{*}}$ (D), R. C. Luz ${ }^{\mathrm{a}}$ (D) and C. K. Peres ${ }^{\mathrm{a}}$ (D) \\ ${ }^{a}$ Universidade Federal da Integração Latino-Americana - UNILA, Instituto Latino-Americano de Ciências da Vida e da Natureza, Foz do Iguaçu, PR, Brasil
}

\begin{abstract}
As a result of biodiversity and ecosystem service losses associated with biological invasions, there has been growing interest in basic and applied research on invasive species aiming to improve management strategies. Tradescantia zebrina is a herbaceous species increasingly reported as invasive in the understory of disturbed forest ecosystems. In this study, we assess the effect of spatial and seasonal variation on biological attributes of this species in the Atlantic Forest. To this end, we measured attributes of T. zebrina associated with plant growth and stress in the four seasons at the forest edge and in the forest interior of invaded sites in the Iguaçu National Park, Southern Brazil. The invasive plant had higher growth at the forest edge than in the forest interior and lower leaf asymmetry and herbivory in the winter than in the summer. Our findings suggest that the forest edge environment favours the growth of $T$. zebrina. This invasive species is highly competitive in the understory of semi-deciduous seasonal forests all over the year. Our study contributes to the management of T. zebrina by showing that the summer is the best season for controlling this species.
\end{abstract}

Keywords: "wandering jew", biological invasions, plant growth, herbivory, invasion management.

\begin{abstract}
Resumo
As perdas de biodiversidade e os seus serviços ecossistêmicos ocasionadas pelas invasões biológicas, têm despertado o interesse em pesquisas básicas e aplicadas sobre as espécies invasoras com o objetivo de buscar estratégias de manejo. Tradescantia zebrina é uma das herbáceas crescentemente relatadas como uma invasora no sub-bosque florestal de ecossistemas impactados. Neste estudo, nós estudamos o efeito da variação espacial e sazonal sobre atributos biológicos desta espécie na Floresta Atlântica. Assim, nós mensuramos atributos de T. zebrina associados com o crescimento vegetal e o estresse nas quatro estações do ano em borda e interior da floresta de locais invadidos no Parque Nacional do Iguaçu, Sul do Brasil. A planta invasora apresentou maior crescimento na borda florestal do que no interior. Adicionalmente, assimetria foliar e herbivoria obtidos no inverno foram menores quando comparados ao verão. Nossos achados sugerem que os ambientes de borda florestal favorecem o crescimento de T. zebrina. Esta espécie invasora é altamente competitiva no sub-bosque da Floresta Estacional Semidecídua durante o ano todo. Nosso estudo contribui com o manejo de T. zebrina mostrando que o verão é a melhor estação para o controle desta espécie.
\end{abstract}

Palavras-chave: "lambari", invasões biológicas, crescimento vegetal, herbivoria, manejo de invasão.

\section{Introduction}

Invasive alien species are one of the major causes of species loss (Newbold et al., 2015), threatening biodiversity conservation (Wittenberg and Cock, 2001) and the provision of ecosystem services (Walsh et al., 2016). In natural ecosystems, the impacts of biological invasions are complex and can permanently alter the structure and function of communities (Panetta and Gooden, 2017), as well as cause local extinctions and homogenize the invaded environment (Sakai et al., 2001).

Environmental degradation has caused biodiversity loss, and has shifted the dynamics of ecosystems, thus promoting the establishment and spread of invasive alien species (Valéry et al., 2008; Zenni, 2010). Nevertheless, alien plants may affect ecosystem processes by changing nutrient cycling, trophic interactions, community structure, and species functional attributes (Dogra et al., 2010), but also by affecting physical properties of ecosystems such as erosion rates, sedimentation, and the water cycle (Wittenberg and Cock, 2001; Ziller, 2001; GISP, 2005; Currie et al., 2014).

Biodiversity loss and landscape changes caused by invasive alien species may be particularly severe in protected areas (FICMNEW, 1998). No Brazilian protected area is known to be free of alien species, although such areas possibly exist (Leão et al., 2011). Ziller and Dechoum (2013) reported

*e-mail: wagner.castro@unila.edu.br; wagner.chiba@gmail.com

Received: May 21, 2020 - Accepted: August 5, 2020 
1,170 invasive alien species occurrences in 227 protected areas in Brazil, associated with 167 species of alien plants and 42 species of alien vertebrates. Despite the fact that the Iguaçu National Park is one of the most important subtropical protected areas in Brazil, it also has a relatively high number (29) of invasive species (Sampaio and Schmidt, 2014).

The wandering jew (Tradescantia zebrina Hort. ex Bosse) is one of the most common invasive alien species in protected areas in Brazil (e.g., Dechoum, 2010; Dickfeldt et al., 2013; Horowitz et al., 2014). This invasive plant has been reported in the Cerrado (Carpanezzi, 2011; Zenni and Ziller, 2011) and in the Atlantic Forest (Rodolfo et al., 2008; Zenni and Ziller, 2011). Tradescantia zebrina is a monotiledoneous plant from the Commelinaceae family likely native to Mexico and Northern Central America (Mantoani et al., 2013), but is currently widely distributed in the world as an introduced species (Instituto Hórus, 2020). It is a $15 \mathrm{~cm}$ to $25 \mathrm{~cm}$ tall perennial herbaceous species, with succulent stems and glabrous leaves with adaxial silver longitudinal stripes and abaxial purple epiderm (Lorenzi and Souza, 2008). Tradescantia zebrina has purple-pink trimerous flowers and produces seeds that are naturally dispersed by physical agents, such as water and wind (Lorenzi and Souza, 2008). The species shows effective vegetative reproduction by stolons throughout the year. Similarly to the congeneric species Tradescantia fluminensis Vell., which is an aggressive invasive species in New Zealand (Standish et al., 2001) and Australia (Dugdale et al., 2015), T. zebrina is more common in forests that are degraded, disturbed, or undergoing natural regeneration (Mantoani et al., 2013; Chiba de Castro et al., 2019).

Considering that invasive alien species often pose a severe threat to protected areas, obtaining basic biological information on these species is crucial (Brugnoli et al., 2009). However, approaches to control of biological invasions have rarely considered the attributes of each target species (Zalba, 2010; Ziller, 2010) Furthermore, delayed actions and poor management decisions often enable invasive species to become widespread, thus making control economically unviable (Simberloff, 2014). Tradescantia zebrina is already considered an invasive species in many continents, including the United States (Burns, 2004), South Africa (Foxcroft et al., 2008), China (Weber et al., 2008), Australia (Biosecurity Queensland, 2016), and Brazil (Zenni and Ziller, 2011). Nevertheless, the mechanisms enabling this species to become dominant in invaded areas are still poorly known, and the little information available is widely scattered (e.g., Burns and Winn, 2006; Carpanezzi, 2011; Mantoani et al., 2013; Chiba de Castro et al., 2019). Detailed information on the biology of invasive species and on how their attributes interact with the invaded environment are critical for developing and validating management strategies (Yokomizo et al., 2009; Simberloff, 2008; Panetta and Gooden, 2017).

In this study, we examine the effect of forest edge and seasonality on biological attributes of T. zebrina in a semideciduous seasonal forest in Southern Brazil. We believe that this invasive species grows better at the border and in the summer, given that it is an important invader at forest edges (Chiba de Castro et al., 2019), and shows high invasiveness under high resource availability (Burns and Winn, 2006). Moreover, we believe that T. zebrina is subjected to more stress in the forest interior and during the winter. Our findings may contribute to the management of T. zebrina by showing i) where and ii) when the species should be controlled.

\section{Material and Methods}

We carried out the study in sites dominated by T. zebrina in the Iguaçu National Park. The Park has an area of $185,262.5$ ha, and is located in the western region of the Parana state, Southern Brazil (25 $05^{\circ}$ to $25^{\circ} 41^{\prime} \mathrm{S}$ and $53^{\circ} 40^{\prime}$ to $54^{\circ} 38^{\prime}$ W) (IBAMA, 2018). The climate in the study region is subtropical Cfa (Köppen's classification) with hot summers (Alvares et al., 2013). The mean annual precipitation ranges from 1,600 to $1,800 \mathrm{~mm}$, with 500 to $600 \mathrm{~mm}$ distributed in the summer, 400 to $500 \mathrm{~mm}$ in the autumn, 300 to $400 \mathrm{~mm}$ in the winter, and 500 to $600 \mathrm{~mm}$ in the spring. The mean annual temperature ranges from 22 to $23^{\circ} \mathrm{C}$, including 25 to $27^{\circ} \mathrm{C}$ in the summer, 21 to $23^{\circ} \mathrm{C}$ in the autumn, 14 to $18{ }^{\circ} \mathrm{C}$ in the winter and 22 to $24{ }^{\circ} \mathrm{C}$ in the spring (IAPAR, 2019). The Iguaçu National Park has the largest remaining area of Atlantic Forest in Southern Brazil, which comprises semi-deciduous seasonal forests, mixed ombrophilous forests and early successional alluvial forests (IBAMA, 2018).

The sites selected for this study are in a region close to the main entrance of the Iguaçu Falls, which is the major tourist attraction in the Iguaçu National Park. All sites were within a radius of $1.5 \mathrm{~km}$ from the following position: $25^{\circ} 37^{\prime} 45^{\prime \prime} \mathrm{S}$ and $54^{\circ} 27^{\prime} 52^{\prime \prime} \mathrm{W}$. The natural vegetation in this region, which is also the dominant vegetation type in the park, is a submontane semi-deciduous seasonal forest. These forests experience a leaf-fall of 20 to $25 \%$ of the trees in the winter, and occur in plain to slightly undulated areas with maximum elevation of $400 \mathrm{~m}$, among other characteristics (IBAMA, 2018).

We sampled five sites with a high level of invasion by T. zebrina (over $80 \%$ of dominance assessed by visual estimation), which were selected based on the following criteria: i) separated by at least $300 \mathrm{~m}$ from each other; ii) belonged to distinct invasions (i.e. discontinuous invaded sites representing different populations); iii) invaded both the forest edge and interior (at least $20 \mathrm{~m}$ towards the forest interior). In each site we considered i) forest edge; and ii) forest interior as distinct spatial treatments, at least $10 \mathrm{~m}$ apart from each other. Three $0.5 \mathrm{~m} \times 0.5 \mathrm{~m}$ quadrats (i.e. $0.75 \mathrm{~m}^{2}$ area) were then randomly allocated in each spatial treatment at each site in the following periods: i) spring (October 2015); ii) summer (January 2016); iii) autumn (May 2016); and iv) winter (September 2016).

In each quadrat we sampled biomass, and morphological and herbivory data of $T$. zebrina. We were unable to obtain the dry biomass of all T. zebrina individuals inside the quadrants due to limitations of laboratory space. Instead, dry biomass data were estimated from fresh biomass measurements performed in the field, in which all individuals of $T$. zebrina were carefully removed from $0.25 \times 0.25 \mathrm{~m}$ quadrats and subsequently weighed. The dry biomass was then estimated using linear regressions 
for each sampling site. These analyses were based on approximately seven fresh biomass samples for each sampling, comprising a variety of weights representative of the biomass variation in our sampling. Fresh biomass samples were oven dried at $60{ }^{\circ} \mathrm{C}$ to constant weight and the resulting dry biomass values were related to the initial fresh biomass values using simple linear regression. We also estimated the number of leaves in a randomly placed biomass subsample within each experimental unit, where the leaves were counted in the laboratory on the following day.

We also obtained leaf area, leaf asymmetry, and herbivory data in each of the three subsamples by quadrat. These measurements were based on ten undamaged stolons from each subsample (30 subsamples across all sites), whose sixth leaf from the apex to the base removed. This approach was derived from field observations aiming to identify the position along stolons of $T$. zebrina that would better reflect the last three months of plant growth. The 30 leaves from each subsample were placed on a white background under transparent glass and photographed with a scale bar. We then measured leaf area and leaf asymmetry (largest size (A)/smallest size (B)) in each image using Image ${ }^{\mathrm{TM}}$. Finally, we quantified the herbivory in each subsample by visually searching for herbivory signs among the 1 st and 6 th leaf of the same ten stolons. The amount of herbivory in each subsample was then calculated as the average percent of leaves showing signs of herbivory.

We assessed the effect of the spatial and seasonal treatments on each attribute of T. zebrina in a randomized block design using Generalized Linear Mixed Models (GLMMs) (Bolker et al., 2009). Response variables were the number of leaves, dry biomass, herbivory rate, average leaf area, and leaf asymmetry in each $0.25 \times 0.25$ quadrat. We assumed a Poisson error distribution in models for the number of leaves, and a Gaussian distribution for other response variables. The fixed effects in each model were spatial treatment, seasonal treatment, and their interaction, and random effects were i) sampling site, ii) spatial treatment nested in site, and iii) seasonal treatment nested in spatial treatment. We performed all analyses in the statistical environment $\mathrm{R}$ ( $\mathrm{R}$ Core Team, 2020). GLMMs for the number of leaves were conducted in the package "Ime4" (Bates et al., 2015), whereas models for the remaining variables were performed in the package "nlme" (Pinheiro et al., 2017); in both cases we used Restricted Maximum Likelihood as the estimation method. When there was a significant effect of seasonal treatment, we used post-hoc pairwise tests in the package "multcomp" (Hothorn et al., 2008) to compare all combinations of treatment levels .

\section{Results}

Our analyses showed that both spatial and seasonal treatments had a significant effect on multiple attributes of T. zebrina, but indicated no significant effect of the interaction between these treatments (Table 1). Regarding the spatial treatment, T. zebrina had a greater number of leaves and higher dry biomass at the forest edge compared to the forest interior (Figure 1). However, there were no significant differences in herbivory, average leaf area, or asymmetry between forest edge and interior (Table 1). For the temporal treatment, pairwise post-hoc comparisons between the four seasons indicated that in the winter T. zebrina had lower dry biomass (Figure 2A) and leaf asymmetry (Figure 2D) than in the summer (summer > winter $=$ spring $>=$ autumn $=$ summer , lower herbivory than in all other seasons (summer $=$ spring $=$ autumn $>$ winter,

Table 1. Effects of spatial (forest edge and interior) and seasonal treatments (Winter, Spring, Summer and Autun) and their interaction on the average values of the number of leaves, dry biomass, herbivory, leaf area and leaf asymmetry of Tradescantia zebrina in invaded areas of the Iguaçu National Park.

\begin{tabular}{|c|c|c|c|c|c|c|c|c|c|c|c|c|c|c|c|}
\hline \multirow{3}{*}{ Treatment } & \multirow{2}{*}{\multicolumn{3}{|c|}{$\begin{array}{c}\text { Number of leaves } \\
\text { (Poisson model) }\end{array}$}} & \multirow{2}{*}{\multicolumn{3}{|c|}{$\begin{array}{c}\text { Dry biomass } \\
\text { (Gaussian model) }\end{array}$}} & \multirow{2}{*}{\multicolumn{3}{|c|}{$\begin{array}{c}\text { Herbivory } \\
\text { (Gaussian model) }\end{array}$}} & \multirow{2}{*}{\multicolumn{3}{|c|}{$\begin{array}{l}\text { Average leaf area } \\
\text { (Gaussian model) }\end{array}$}} & \multirow{2}{*}{\multicolumn{3}{|c|}{$\begin{array}{c}\text { Leaf assimetry } \\
\text { (Gaussian model) }\end{array}$}} \\
\hline & & & & & & & & & & & & & & & \\
\hline & estimate & $\begin{array}{l}\text { std. } \\
\text { error }\end{array}$ & z-value & value & $\begin{array}{l}\text { std. } \\
\text { error }\end{array}$ & t-value & value & $\begin{array}{l}\text { std. } \\
\text { error }\end{array}$ & t-value & value & $\begin{array}{l}\text { std. } \\
\text { error }\end{array}$ & t-value & value & $\begin{array}{l}\text { std. } \\
\text { error }\end{array}$ & t-value \\
\hline Intercept & 6.63 & 0.15 & $43.91^{* * *}$ & 38.0 & 4.77 & 7.97 & 19.11 & 3.31 & 5.78 & 11.20 & 0.98 & $11.44^{* * *}$ & 1.13 & 0.01 & $82.65^{* * *}$ \\
\hline $\begin{array}{l}\text { Spatial } \\
\text { (forest } \\
\text { interior) }\end{array}$ & -1.19 & 0.22 & $-5.55^{* * *}$ & -27.8 & 6.58 & $-4.22^{*}$ & 8.67 & 4.06 & 2.13 & -2.39 & 1.38 & -1.73 & 0.00 & 0.02 & 0.10 \\
\hline Autumn & 0.04 & 0.18 & 0.20 & 4.8 & 5.60 & 0.86 & 11.66 & 4.04 & $2.88^{*}$ & 1.78 & 0.80 & $2.23^{*}$ & -0.01 & 0.02 & -0.42 \\
\hline Spring & -0.02 & 0.18 & -0.13 & -1.6 & 5.60 & -0.29 & 9.89 & 4.04 & $2.45^{*}$ & 1.42 & 0.80 & 1.78 & -0.01 & 0.02 & -0.52 \\
\hline Summer & -0.11 & 0.18 & -0.60 & 12.8 & 5.60 & $2.29^{*}$ & 16.55 & 4.04 & $4.09^{*}$ & 4.58 & 0.80 & $5.74^{* * *}$ & 0.04 & 0.02 & $2.09^{*}$ \\
\hline $\begin{array}{l}\text { Spatial } \times \\
\text { Autumn }\end{array}$ & 0.17 & 0.25 & 0.68 & -4.6 & 7.92 & -0.58 & -11.44 & 5.72 & -2.00 & -0.28 & 1.13 & -2.46 & 0.04 & 0.03 & 1.40 \\
\hline $\begin{array}{l}\text { Spatial × } \\
\text { Spring }\end{array}$ & 0.44 & 0.25 & 0.17 & 4.2 & 7.92 & 0.53 & -5.22 & 5.72 & -0.91 & -0.59 & 1.13 & -0.53 & -0.02 & 0.03 & -0.74 \\
\hline $\begin{array}{l}\text { Spatial } \times \\
\text { Summer }\end{array}$ & 0.44 & 0.25 & 0.17 & -7.2 & 7.92 & -0.91 & -6.78 & 5.72 & -1.19 & -1.86 & 1.13 & -1.65 & -0.03 & 0.03 & -1.04 \\
\hline
\end{tabular}


autumn, Figure 2C). The number of leaves of T. zebrina did not differ significantly among the four seasons (Table 1 ).
Figure as 2B), and lower leaf area than in the summer and in the autumn $($ summer $>$ autumn $>$ winter $=$ spring $=$

A

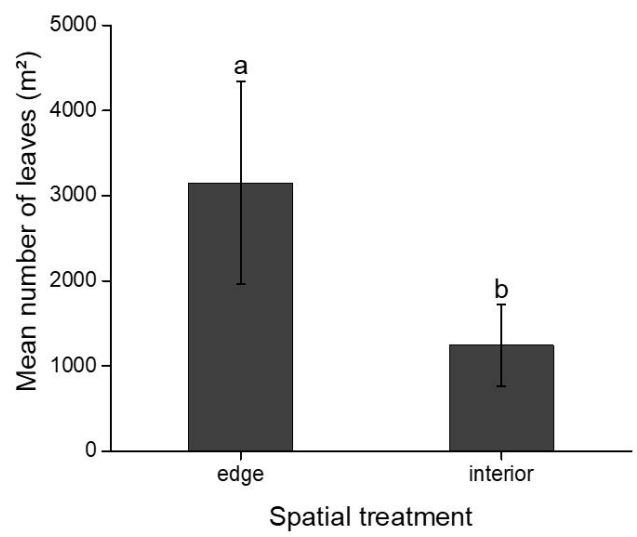

Figure 1. Mean numbers of leaves (A) and dry biomass (B) of Tradescantia zebrina in the spatial treatment (forest edge and interior) in invaded areas of the Iguaçu National Park. Error bars are standard deviation. Different letters indicate a significant difference between treatments.
B

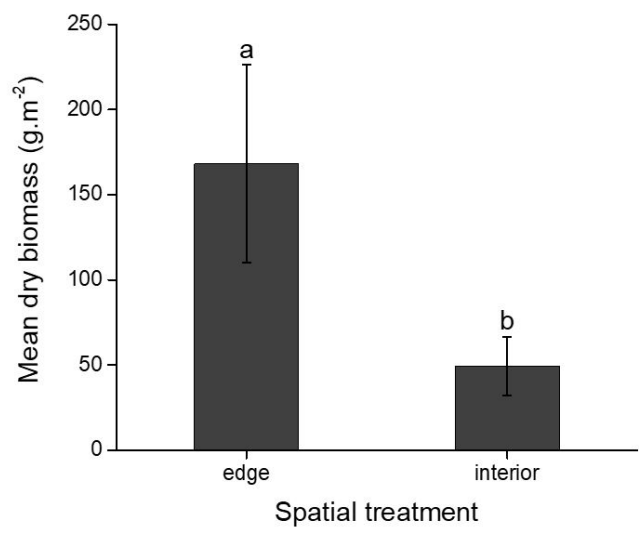

A

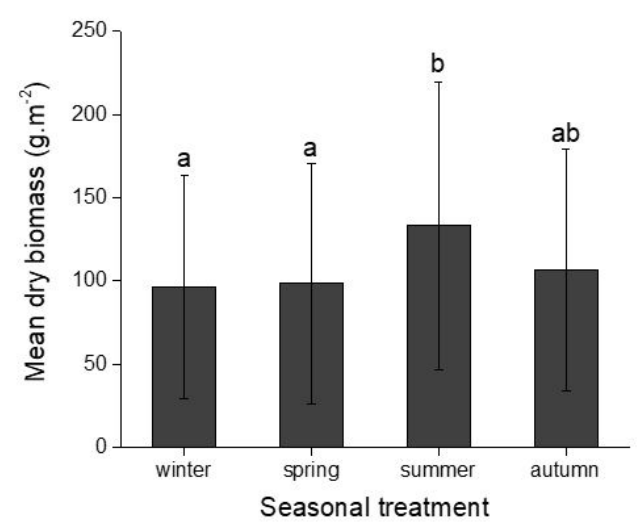

C

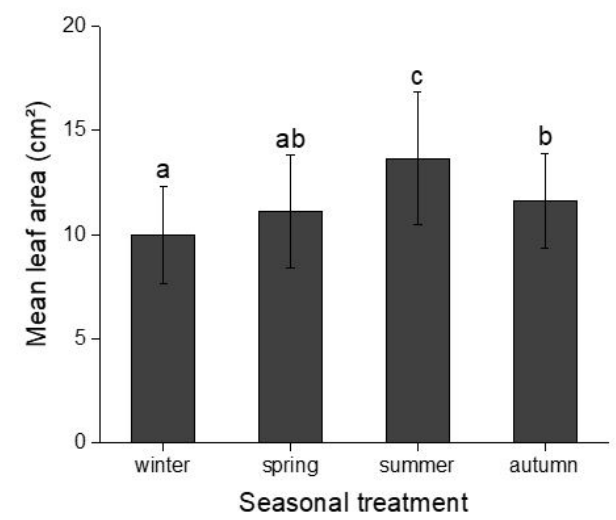

B

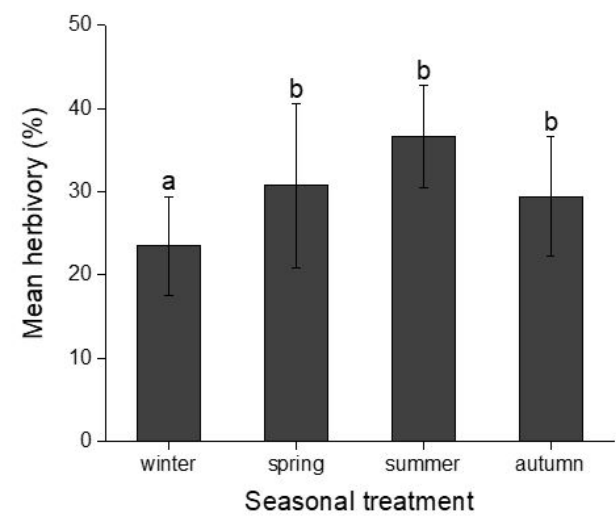

D

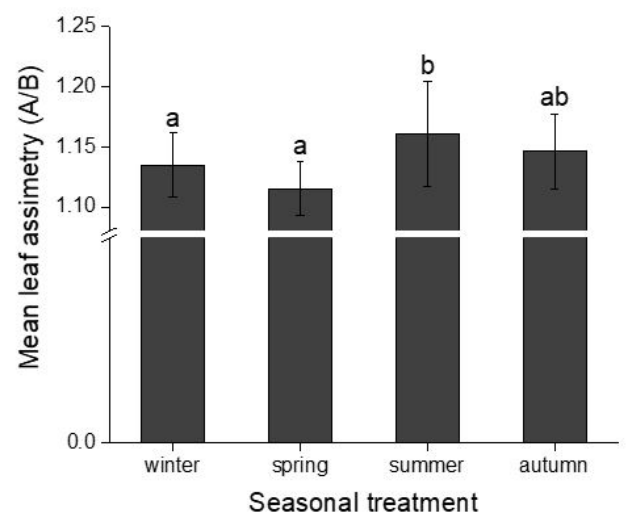

Figure 2. Mean numbers of dry biomass (A), leaf herbivory (B), leaf area (C) and leaf asymmetry (D) of Tradescantia zebrina in seasonal treatment (Winter, Spring, Summer and Autumn) in invaded areas of the Iguaçu National Park. Error bars are standard deviation. The same letter indicates that there is no significant difference between treatments (a posteriori test of general linear hypothesis; $\mathrm{p}<0.05$ ). 


\section{Discussion}

Our results demonstrate that both forest edge effects and climatic seasonality affect biological attributes of T. zebrina. We found that this invader has a greater number of leaves and produces more biomass at the forest edge than in the forest interior, suggesting that growing conditions at the edge of semi-deciduous forests favour this species. Edges of forest fragments are often vulnerable to invasions by alien plants, especially along roads, where native vegetation cover and species richness are generally low (Catford et al., 2011). In our study the high dominance of $T$. zebrina at the forest edge may be associated with increased photosynthetic and relative growth rates under high resource availability (Burns, 2004), particularly as a result of high light availability compared to the forest interior (Yamashita et al., 2000). This preference for forest edges also suggests that the control of this species in the Atlantic Forest is more likely to succeed in the forest interior, as in this environment the regenerative potential of native tree species tends to be high, and both the biomass production and ability to recovery from mechanical removal shown by T. zebrina are lower in the interior than at the forest edge (Chiba de Castro et al., 2019). Nevertheless, controlling invasions both at the forest edge and in the forest interior can increase the likelihood of management success, given that forest edges invaded by T. zebrina may act as a large source of propagules to invasions in the forest interior, as has been reported for other invasive plants (Cadenasso and Pickett, 2001; Lambrinos, 2006; Thomas and Moloney, 2015).

Seasonality effects, especially the influence of seasonal treatments on the number of leaves of T. zebrina, were the most surprising results of our study, as they did not corroborate our initial hypothesis. Although we sampled a semi-deciduous forest that experiences relatively low temperature and precipitation in the winter, in our study the number of leaves of T. zebrina did not show seasonal variation. Other studies also investigated the role of seasonality in the competitive ability of invasive herbaceous species. For example, Bromus tectorum L. is a highly invasive grass in the western United States, where its seeds germinate in the autumn; this seasonal pattern is advantageous for the species, as it matches with the beginning of the senescence of native grasses in this region (Knapp, 1996). Likewise, early winter growth compared to the native community is the main competitive advantage of the invasive grass Arundo donax L. (Decruyenaere and Holt, 2005). Considering that T. zebrina also showed low biomass and leaf area in the winter, we believe that the lack of seasonal variation in the number of leaves shown by this species is associated with rapid leaf replacement; therefore, small leaves sampled in the winter were possibly newly produced and hence we found no annual variation in the number of leaves. A similar phenomenon was described for Hedychium coronarium J. Koenig, a rhizomatous herbaceous species whose ramets are replaced during the winter, and thereby suppress the germination of native species in the spring (Chiba de Castro et al., 2016, 2020). Therefore, we believe that replacing leaves in the winter may confer a competitive advantage to T. zebrina over native species in the understory of the Atlantic Forest.

Contrasting with our initial hypothesis, T. zebrina exhibited maximum leaf asymmetry in the summer, suggesting that conditions are more stressful to this species in this season than in the winter. Leaf asymmetry can be influenced by multiple abiotic factors, such as level of pollution, altitude, soil moisture, and temperature (Beasley et al., 2013; Maldonado-López et al., 2019). For instance, a variety of studies have found close association between low soil moisture and high leaf asymmetry (Orians and Solbrig, 1977; Nagamitsu et al., 2004; Souza et al., 2005). Likewise, the alien tree Ficus carica L. exhibited high leaf asymmetry early in the spring in the southeastern United States, where the winter is significantly colder than in its native range, thus also suggesting a relationship between temperate and leaf stress (Cowart and Graham, 1999). While we expected that T. zebrina would be more subjected to stress in the winter, given that in the subtropical Atlantic Forest this season is considerably colder and drier than in the summer, and T. zebrina is native to the tropics, the species exhibited maximum leaf asymmetry in the summer. We believe that this pattern is associated with high leaf herbivory in the summer. Multiple studies have found positive association between leaf asymmetry and herbivory rate (Cornelissen and Stiling, 2005; Cuevas-Reyes et al., 2011; Beasley et al., 2013; Maldonado-López et al., 2019). Mari and Galassi (2010) demonstrated that herbivory pressure increased in the summer and decreased in the cold season. Importantly, despite the fact that T. zebrina produced more biomass at the border than in the forest interior, the amount of herbivory did not differ between these environments. This finding suggests that herbivory pressure was consistent with plant density and hence high plant biomass at the forest edge did not attract more herbivores. Furthermore, it is well known that higher temperatures may stimulate herbivory activity (Heiler et al., 2008; O'Connor, 2009; Lemoine et al., 2014), which is also in agreement with our results. In addition to warm temperatures, rainy seasons also favour the development of herbivorous insects (Araujo et al., 2013). For example, Cerrado insects are seasonally distributed over the year, with most of them occurring in the rainy season (81.1\%) (Oliveira and Frizzas, 2008). In December 2015 , which coincides with the summer treatment in our experiment, the precipitation in our study region ranged from 350 to $400 \mathrm{~mm}$. This precipitation accumulation in a single month represents 20 to $25 \%$ of the average annual precipitation. Therefore, in our study region both high temperature and high precipitation in the summer seem to provide optimal conditions for herbivorous insects.

Our results suggest that in the Atlantic Forest T. zebrina should be controlled in the summer. This recommendation is mostly based both on i) the lack of seasonal variation in the number of leaves; and ii) on the higher herbivory pressure in the summer. Results on the leaf area and number of leaves of $T$. zebrina in our study are consistent with those found by Chiba de Castro et al. (2019), which reported rapid leaf regrowth for this species. This effective recovery from defoliation is also corroborated by the 
failure of previous attempts to use mechanical removal for controlling T. zebrina in the Iguaçu National Park (ICMBio, personal communication). Effective leaf regrowth is also expected following management actions in the summer, so that even after being removed during this season, T. zebrina may show a rapid recovery supported by newly grown leaves. However, it is well established that herbivory pressure tends to be much higher in young than in mature leaves (Crawley, 1989). Considering that even herbivory on mature leaves may lead to stress, as suggested by our leaf asymmetry findings, this negative effect is likely even higher on young leaves. Therefore, herbivory possibly decreases the performance of T. zebrina in the summer and hence would increase the efficiency of managing the species during this season.

Overall, our findings show that conditions at the forest edge are more suitable to the growth of T. zebrina than those in the forest interior. Maintaining a high number of leaves throughout the year enables this species to be an excellent competitor in the understory of subtropical semi-deciduous seasonal forests High biomass and leaf area in the summer suggest that most of the leaves of T. zebrina reach maturity in this season, when herbivory is maximal and appears to increase leaf asymmetry. Our study contributes to a more effective management of T. zebrina by suggesting that the summer is the best season to control the species in the Atlantic Forest.

\section{Acknowledgements}

We thank the UNILA - PRPPG for funding this study, and Jair Hernando Castro Romero, Federico Hernan Garrido de Leon, Josiane Pereira Lana, Maria Cecília Fachinello, and Waldemar Lopes da Silva Netto for their assistance during the fieldwork. We are also thankful to A Sibim and T. Riofi, respectively, for their dedication to Pedro and Clara during the COVID-19 pandemic lockdown, thus allowing the first and third authors to lead the writing of this manuscript. This study was supported by the Federal University of Latin American Integration (UNILA-PRPPG) under EDITAL PRPPG № 137.

\section{References}

ALVARES, C.A., STAPE, J.L., SENTELHAS, P.C., GONÇALVES, J.L.M. and SPAROVEK, G., 2013. Köppen's climate classification map for Brazil. Meteorologische Zeitschrift, vol. 22, no. 6, pp. 711-728. http://dx.doi.org/10.1127/0941-2948/2013/0507.

ARAÚJO, W.S., SCARELI-SANTOS, C., GUILHERME, F.A.G. and CUEVAS-REYES, P., 2013. Comparing galling insect richness among Neotropical savannas: effects of plant richness, vegetation structure and super-host presence. Biodiversity and Conservation, vol. 22, no. 4, pp. 1083-1094. http://dx.doi. org/10.1007/s 10531-013-0474-8.

BATES, D., MAECHLER, M., BOLKER, B., WALKER, S., CHRISTENSEN, R.H.B. and SINGMANN, H., 2015 [viewed 31 March 2020]. lme4: linear mixed-effects models using Eigen and S4, 2014. $R$ package version 1 [online]. Vienna: R Foundation for Statistical Computing. Available from: https://cran.r-project.org/web/ packages/lme4/index.html
BEASLEY, D.E., BONISOLI-ALQUATI, A. and MOUSSEAU, T.A., 2013. The use of fluctuating asymmetry as a measure of environmentally induced developmental instability: a meta-analysis. Ecological Indicators, vol. 30, pp. 218-226. http://dx.doi.org/10.1016/j. ecolind.2013.02.024.

BIOSECURITY QUEENSLAND, 2016. Fact sheet: Zebrina. Queensland: Biosecurity Queensland, $2 \mathrm{p}$.

BOLKER, B.M., BROOKS, M.E., CLARK, C.J., GEANGE, S.W., POULSEN, J.R., STEVENS, M.H.H. and WHITE, J.S.S., 2009. Generalized linear mixed models: a practical guide for ecology and evolution. Trends in Ecology E'Evolution, vol. 24, no. 3, pp. 127-135. http:// dx.doi.org/10.1016/j.tree.2008.10.008. PMid:19185386.

BRUGNOLI, E., MASCIADRI, S. and MUNIZ, P., 2009. Base de datos de especies exóticas e invasoras en Uruguay, un instrumento para la gestión ambiental y costera. Montevideo: Programa Ecoplata, $24 \mathrm{p}$.

BURNS, J.H. and WINN, A.A.A., 2006. A comparison of plastic responses to competition by invasive and non-invasive congeners in the Commelinaceae. Biological Invasions, vol. 8, no. 4, pp. 797-807. http://dx.doi.org/10.1007/s10530-005-3838-5.

BURNS, J.H., 2004. A comparison of invasive and non-invasive dayflowers (Commelinaceae) across experimental nutrient and water gradients. Diversity \& Distributions, vol. 10, no. 5-6, pp. 387-397. http://dx.doi.org/10.1111/j.1366-9516.2004.00105.x.

CADENASSO, M.L. and PICKETT, S.T.A., 2001. Effect of edge structure on the flux of species into forest interiors. Conservation Biology, vol. 15, no. 1, pp. 91-97. http://dx.doi.org/10.1111/j.15231739.2001.99309.x.

CARPANEZZI, O.T.B., 2011 [viewed 8 July 2020]. Espécies exóticas no Parque Estadual de Vila Velha: subsídios para controle e erradicação. In: O.T.B. CARPANEZZI and J.B. CAMPOS, eds. Coletânea de pesquisa: Parques Estaduais de Vila Velha, Cerrado e Guartelá [online]. Curitiba: Instituto Ambiental do Paraná. Available from: http://www.iap.pr.gov.br/arquivos/File/ Publicacoes/Livros/Livro_PEVV_arrumado.pdf

CATFORD, J.A., VESK, P.A., WHITE, M.D. and WINTLE, B.A., 2011. Hotspots of plant invasion predicted by propagule pressure and ecosystem characteristics. Diversity \& Distributions, vol. 17, no. 6, pp. 1099-1110. http://dx.doi.org/10.1111/j.14724642.2011.00794.x.

CHIBA DE CASTRO, W., ALMEIDA, R., LEITE, M., MARRS, R. and MATOS, D.S., 2016. Invasion strategies of the white ginger lily Hedychium coronarium J. König (Zingiberaceae) under different competitive and environmental conditions. Environmental and Experimental Botany, vol. 127, pp. 55-62. http://dx.doi. org/10.1016/j.envexpbot.2016.03.010.

CHIBA DE CASTRO, W.A., ALMEIDA, R.V., XAVIER, R.O., BIANCHINI JUNIOR, I., MOYA, H. and SILVA MATOS, D.M., 2020. Litter accumulation and biomass dynamics in riparian zones in tropical South America of the Asian invasive plant Hedychium coronarium J. König (Zingiberaceae). Plant Ecology \& Diversity, vol. 13, no. 1, pp. 47-59. http://dx.doi.org/10.1080/17550874. 2019.1673496.

CHIBA DE CASTRO, W.A., XAVIER, R.O., GARRIDO, F.H., ROMERO, J.H., PERES, C.K. and LUZ, R.C., 2019. Fraying around the edges: negative effects of the invasive Tradescantia zebrina Hort. ex Bosse (Commelinaceae) on tree regeneration in the Atlantic Forest under different competitive and environmental conditions. Journal of Plant Ecology, vol. 12, no. 4, pp. 713-721. http://dx.doi.org/10.1093/jpe/rtz009.

CORNELISSEN, T. and STILING, P., 2005. Perfect is best: low leaf fluctuating asymmetry reduces herbivory by leaf miners. Oecologia, vol. 142, no. 1, pp. 46-56. http://dx.doi.org/10.1007/ s00442-004-1724-y. PMid:15378348. 
COWART, N.M. and GRAHAM, J.H., 1999. Within- and amongindividual variation in fluctuating asymmetry of leaves in the Fig (Ficus carica L.). International Journal of Plant Sciences, vol. 160, no. 1, pp. 116-121. http://dx.doi.org/10.1086/314104.

CRAWLEY, M.J., 1989. Insect herbivores and plant population dynamics. Annual Review of Entomology, vol. 34, no. 1, pp. 531562. http://dx.doi.org/10.1146/annurev.en.34.010189.002531.

CUEVAS-REYES, P., OLIVEIRA-KER, F.T., FERNANDES, G.W. and BUSTAMANTE, M., 2011. Abundance of gall-inducing insect species in sclerophyllous savanna: understanding the importance of soil fertility using an experimental approach. Journal of Tropical Ecology, vol. 27, no. 6, pp. 631-640. http:// dx.doi.org/10.1017/S0266467411000368.

CURRIE, W.S., GOLDBERG, D.E., MARTINA, J., WILDOVA, R., FARRER, E. and ELGERSMA, K.J., 2014. Emergence of nutrient-cycling feedbacks related to plant size and invasion success in a wetland community-ecosystem model. Ecological Modelling, vol. 282, pp. 69-82. http://dx.doi.org/10.1016/j.ecolmodel.2014.01.010.

DECHOUM, M.S., 2010. Espécies exóticas invasoras: o contexto internacional e a construção de políticas públicas e de estratégias nacionais. São Paulo: Secretaria de Estado do Meio Ambiente. Cadernos da Mata Ciliar: Espécies Exóticas Invasoras, no. 3.

DECRUYENAERE, J.G. and HOLT, J.S., 2005. Ramet demography of a clonal invader, Arundo donax (Poaceae), in Southern California. Plant and Soil, vol. 277, no. 1-2, pp. 41-52. http:// dx.doi.org/10.1007/s11104-005-0264-5.

DICKFELDT, E.P., JANDUCCI, B.Z. and SOUZA, S.A., 2013. Levantamento das espécies vegetais exóticas e experiências de manejo no parque estadual de Porto Ferreira, SP. Periódico Eletrônico Fórum Ambiental da Alta Paulista, vol. 9, no. 3, pp. 1-20. http://dx.doi. org/10.17271/19800827932013608.

DOGRA, K.S., SOOD, S.K., DOBHAL, P.K. and SHARMA, S., 2010. Alien plant invasion and their impact on indigenous species diversity at global scale: a review. Journal of Ecology and the Natural Environment, vol. 2, no. 9, pp. 175-186.

DUGDALE, T.M., MCLAREN, D.A. and CONRAN, J.G., 2015. The biology of Australian weeds 65. Tradescantia fluminensis Vell. Plant Protection Quarterly, vol. 30, no. 4, pp. 116-125.

FEDERAL INTERAGENCY COMMITTEE FOR THE MANAGEMENT OF NOXIOUS AND EXOTIC WEEDS - FICMNEW, 1998 [viewed 4 April 2020]. Invasive plants: changing the landscape of America [online]. Utah: All U.S. Government Documents, Utah Regional Depository. Paper, no. 490. Available from: https:// digitalcommons.usu.edu/govdocs/490

FOXCROFT, L.C., RICHARDSON, D.M. and WILSON, J.R., 2008. Ornamental plants as invasive aliens: problems and solutions in Kruger National Park, South Africa. Environmental Management, vol. 41, no. 1, pp. 32-51. http://dx.doi.org/10.1007/s00267-0079027-9. PMid:17943344.

HEILER, K.C.M., VON OHEIMB, P.V., EKSCHMITT, K. and ALBRECHT, C., 2008. Studies on the temperature dependence of activity and on the diurnal activity rhythm of the invasive Pomacea canaliculata (Gastropoda: ampullariidae). Mollusca, vol. 26, pp. 73-81.

HOROWITZ, C., MARTINS, C.R. and WALTER, B.M.T., 2014. Flora exótica no Parque Nacional de Brasília: levantamento e classificação das espécies. Biodiversidade Brasileira, no. 2, pp. 50-73.

HOTHORN, T., BRETZ, F. and WESTFALL, P., 2008. Simultaneous inference in general parametric models. Biometrical Journal. Biometrische Zeitschrift, vol. 50, no. 3, pp.346-363. http://dx.doi. org/10.1002/bimj.200810425. PMid:18481363.
INSTITUTO AGRONÔMICO DO PARANÁ - IAPAR, 2019 [viewed 4 April 2020]. Atlas climático do estado do Paraná [online]. Available from: http://www.iapar.br/modules/conteudo/ conteudo.php?conteudo $=604$

INSTITUTO BRASILEIRO DE MEIO AMBIENTE E DOS RECURSOS NATURAIS RENOVÁVEIS - IBAMA, 2018 [viewed 25 March 2020]. Plano de manejo do parque Nacional do Iguaçu [online]. Brasília. Available from: https://www.icmbio.gov.br/portal/ images/stories/plano-de-manejo/plano_de_manejo_do_parna_ do_iguacu_fevereiro_2018.pdf

INSTITUTO HÓRUS DE DESENVOLVIMENTO E CONSERVAÇÃO AMBIENTAL - INSTITUTO HÓRUS, 2020 [viewed 15 March 2020]. Espécies invasoras brasileiras [online]. Available from: https://institutohorus.com/

KNAPP, P.A., 1996. Cheatgrass (Bromus tectorum L.) dominance in the Great Basin Desert. Global Environmental Change, vol. 6, no. 1, pp. 37-52. http://dx.doi.org/10.1016/0959-3780(95)00112-3.

LAMBRINOS, J.G., 2006. Spatially variable propagule pressure and herbivory influence invasion of chaparral shrubland by an exotic grass. Oecologia, vol. 147, no. 2, pp. 327-334. http:// dx.doi.org/10.1007/s00442-005-0259-1. PMid:16189663.

LEÃO, T.C.C., ALMEIDA, W.R., DECHOUM, M. and ZILLER, S.R., 2011. Espécies exóticas invasoras no Nordeste do Brasil: contextualização, manejo e políticas públicas. Recife: Centro de Pesquisas Ambientais do Nordeste e Instituto Hórus de Desenvolvimento e Conservação Ambiental, 99 p.

LEMOINE, N.P., BURKEPILE, D.E. and PARKER, J.D., 2014. Variable effects of temperature on insect herbivory. PeerJ, vol. 2, e376. http://dx.doi.org/10.7717/peerj.376. PMid:24860701.

LORENZI, H. and SOUZA, H.M., 2008. Plantas ornamentais no Brasil: arbustivas, herbáceas e trepadeiras. 4. ed. São Paulo: Instituto Plantarum, $1120 \mathrm{p}$.

MALDONADO-LÓPEZ, Y., VACA-SÁNCHEZ, M.S., CANCHÉ-DELGADO, A., GARCÍA-JAÍN, S.E., GONZÁLEZ-RODRÍGUEZ, A., CORNELISSEN, T. and CUEVAS-REYES, P., 2019. Leaf herbivory and fluctuating asymmetry as indicators of mangrove stress. Wetlands Ecology and Management, vol. 27, no. 4, pp. 571-580. http://dx.doi. org/10.1007/s11273-019-09678-z.

MANTOANI, M.C., DIAS, J., ORSI, M.L. and TOREZAN, J.M.D., 2013. Efeitos da invasão por Tradescantia zebrina Heynh. sobre regenerantes de plantas arbóreas em um fragmento de floresta estacional semidecidual secundária em Londrina (PR). Biotemas, vol. 26, no. 3, pp. 63-70. http://dx.doi.org/10.5007/21757925.2013v26n3p63.

MARI, E.K. and GALASSI, M.E., 2010. ¿Factores ambientales o herbivoría controlan la emergencia de plántulas en un bosque fluvial del río Paraná. Interciencia, vol. 35, no. 8, pp. 605-612.

NAGAMITSU, T., KAWAHARA, T. and HOTTA, M., 2004. Phenotypic variation and leaf fluctuating asymmetry in isolated populations of an endangered dwarf birch Betula ovalifolia in Hokkaido, Japan. Plant Species Biology, vol. 19, no. 1, pp. 13-21. http:// dx.doi.org/10.1111/j.1442-1984.2004.00097.x.

NEWBOLD, T., HUDSON, L.N., HILL, S.L.L., CONTU, S., LYSENKO, I., SENIOR, R.A., BÖRGER, L., BENNETT, D.J., CHOIMES, A., COLLEN, B., DAY, J., DE PALMA, A., DÍAZ, S., ECHEVERRIA-LONDOÑO, S., EDGAR, M.J., FELDMAN, A., GARON, M., HARRISON, M.L.K., ALHUSSEINI, T., INGRAM, D.J., ITESCU, Y., KATTGE, J., KEMP, V., KIRKPATRICK, L., KLEYER, M., CORREIA, D.L.P., MARTIN, C.D., MEIRI, S., NOVOSOLOV, M., PAN, Y., PHILLIPS, H.R.P., PURVES, D.W., ROBINSON, A., SIMPSON, J., TUCK, S.L., WEIHER, E., WHITE, H.J., EWERS, R.M., MACE, G.M., SCHARLEMANN, J.P.W. and PURVIS, A., 2015. Global effects of land use on local terrestrial 
biodiversity. Nature, vol. 520, no. 7545 , pp. 45-50. http://dx.doi. org/10.1038/nature14324. PMid:25832402.

O'CONNOR, M.I., 2009. Warming strengthens an herbivore-plant interaction. Ecology, vol. 90, no. 2, pp. 388-398. http://dx.doi. org/10.1890/08-0034.1. PMid:19323223.

OLIVEIRA, C.M. and FRIZZAS, M.R., 2008. Insetos do Cerrado: distribuição estacional e abundância. Planaltina: Embrapa Cerrados, 216 p. Boletim de Pesquisa e Desenvolvimento.

ORIANS, G.H. and SOLBRIG, O.T., 1977. A cost-income model of leaves and roots with special reference to arid and semiarid areas. American Naturalist, vol. 111, no. 980, pp. 677-690. http:// dx.doi.org/10.1086/283199.

PANETTA, F.D. and GOODEN, B., 2017. Managing for biodiversity: impact and action thresholds for invasive plants in natural ecosystems. NeoBiota, vol. 34, pp. 53-66. http://dx.doi. org/10.3897/neobiota.34.11821.

PINHEIRO,J., BATES, D., DEBROY,S. and SARKAR, D. 2017 [viewed 31 March 2020].nlme: linear and nonlinear mixed effects models. R package version 3.1-131 [online]. Vienna: R Foundation for Statistical Computing. Available from: https://CRAN.R-project.org/package=nlme

PROGRAMA GLOBAL DE ESPÉCIES INVASORAS - GISP, (2005). América do Sul invadida: a crescente ameaça das espécies exóticas. Nairobi: GISP, 80 p.

R CORE TEAM, 2020 [viewed 31 March 2020]. R: a language and environment for statistical computing [online]. Vienna: R Foundation for Statistical Computing. Available from: www.r-project.org

RODOLFO, A.M., TEMPONI, L.G. and CÂNDIDO JUNIOR, J.F.C., 2008. Levantamento de plantas exóticas na trilha do Poço Preto, Parque Nacional do Iguaçu, Paraná, Brasil. Revista Brasileira de Biociências, vol. 6, no. 1, pp. 22-24.

SAKAI, A.K., ALLENDORF, F.W., HOLT, J.S., LODGE, D.M., MOLOFSKY, J., WITH, K.A., BAUGHMAN, S., CABIN, R.J., COHEN, J.E., ELLSTRAND, N.C., MCCAULEY, D.E., O'NEIL, P., PARKER, I.M., THOMPSON, J.N. and WELLER, S.G., 2001. The population biology of invasive species. Annual Review of Ecology and Systematics, vol. 32, no. 1, pp. 305-332. http://dx.doi.org/10.1146/annurev. ecolsys.32.081501.114037.

SAMPAIO, A.B. and SCHMIDT, I.B., 2014. Espécies exóticas invasoras em unidades de conservação federais do Brasil. Biodiversidade Brasileira, no. 2, pp. 32-49.

SIMBERLOFF, D., 2008. We can eliminate invasions or live with them: successful management projects. Dordrecht: Springer, pp. 149-157.

SIMBERLOFF, D., 2014. Biological invasions: what's worth fighting and what can be won? Ecological Engineering, vol. 65, pp. 112121. http://dx.doi.org/10.1016/j.ecoleng.2013.08.004.

SOUZA, G.M., VIANA, J.O.F. and OLIVEIRA, R.F., 2005. Asymmetrical leaves induced by water deficit show asymmetric photosynthesis in common bean. Brazilian Journal of Plant Physiology, vol. 17, no. 2, pp. 223-227. http://dx.doi.org/10.1590/S167704202005000200005.

STANDISH, R.J., ROBERTSON, A.W. and WILLIAMS, P.A., 2001. The impact of an invasive weed Tradescantia fluminensis on native forest regeneration. Journal of Applied Ecology, vol. 38, no. 6, pp. 1253-1263. http://dx.doi.org/10.1046/j.0021-8901.2001.00673.x.
THOMAS, S.M. and MOLONEY, K.A., 2015. Combining the effects of surrounding land-use and propagule pressure to predict the distribution of an invasive plant. Biological Invasions, vol. 17, no. 1, pp. 477-495. http://dx.doi.org/10.1007/s10530-014-0745-7.

VALÉRY, L., FRITZ, H., LEFEUVRE, J.C. and SIMBERLOFF, D., 2008. In search of a real definition of the biological invasion phenomenon itself. Biological Invasions, vol. 10, no. 8, pp. 1345-1351. http:// dx.doi.org/10.1007/s10530-007-9209-7.

WALSH, J.R., CARPENTER, S.R. and VANDER ZANDEN, M.J., 2016. Invasive species triggers a massive loss of ecosystem services through a trophic cascade. Proceedings of the National Academy of Sciences of the United States of America, vol. 113, no. 15, pp. 4081-4085. http://dx.doi.org/10.1073/pnas.1600366113. PMid:27001838.

WEBER, E., SUN, S. and LI, B., 2008. Invasive alien plants in China: diversity and ecological insights. Biological Invasions, vol. 10, no. 8, pp. 1411-1429. http://dx.doi.org/10.1007/ s10530-008-9216-3.

WITTENBERG, R. and COCK, M.J.W., eds., 2001. Invasive alien species: a toolkit of best prevention and management practices. Wallingford: CAB International, 228 p. http://dx.doi. org/10.1079/9780851995694.0000.

YAMASHITA, N., ISHIDA, A., KUSHIMA, H. and TANAKA, N., 2000. Acclimation to sudden increase in light favouring an invasive over native trees in subtropical islands, Japan. Oecologia, vol. 125, no. 3, pp. 412-419. http://dx.doi.org/10.1007/s004420000475. PMid:28547336.

YOKOMIZO, H., POSSINGHAM, H.P., THOMAS, M.B. and BUCKLEY, Y.M., 2009. Managing the impact of invasive species: the value of knowing the density-impact curve. Ecological Applications, vol. 19, no. 2, pp. 376-386. http://dx.doi.org/10.1890/08-0442.1. PMid:19323196.

ZALBA, S.M., 2010. Controle de espécies exóticas invasoras em áreas protegidas naturais: aprender fazendo. São Paulo: Secretaria de Estado do Meio Ambiente. Cadernos da Mata Ciliar: Espécies Exóticas Invasoras, no. 3.

ZENNI, R.D., 2010. Manejo de plantas exóticas invasoras em planos de restauração de ambientes naturais. São Paulo: Secretaria de Estado do Meio Ambiente, pp. 17-22. Cadernos da Mata Ciliar, Espécies Exóticas Invasoras.

ZENNI, R.D. and ZILLER, S.R., 2011. An overview of invasive plants in Brazil. Revista Brasileira de Botânica, vol. 34, no. 3, pp. 431446. http://dx.doi.org/10.1590/S0100-84042011000300016.

ZILLER, S.R., 2001. Plantas exóticas invasoras: a ameaça da contaminação biológica. Revista Ciência Hoje, vol. 30, no. 178, pp. 77-79.

ZILLER, S.R., 2010. Como estabelecer prioridades para ações de controle de espécies exóticas invasoras em escala estadual. São Paulo: Secretaria de Estado do Meio Ambiente, pp. 12-16. Cadernos da Mata Ciliar: Espécies Exóticas Invasoras.

ZILLER, S.R. and DECHOUM, M.S., 2013. Plantas e vertebrados exóticos invasores em unidades de conservação no Brasil. Biodiversidade Brasileira, no. 2, pp. 4-31. 